\title{
CUNEGEO
}

International Journal of Environment and Geoinformatics (IJEGEO) is an international, multidisciplinary, peer reviewed, open access journal.

\section{Calculation of Aircraft Emissions during Landing and Take-Off (LTO) Cycles at Batumi International Airport, Georgia}

\section{Aydin TOKUŞLU}

\author{
Chief in Editor \\ Prof. Dr. Cem Gazioğlu \\ Co-Editors
}

Prof. Dr. Dursun Zafer Şeker, Prof. Dr. Şinasi Kaya,

Prof. Dr. Ayşegül Tanık and Assist. Prof. Dr. Volkan Demir

Editorial Committee (June 2021)

Assoc. Prof. Dr. Abdullah Aksu (TR), Assit. Prof. Dr. Uğur Algancı (TR), Prof. Dr. Bedri Alpar (TR), Assoc. Prof. Dr. Aslı Aslan (US), Prof. Dr. Levent Bat (TR), Prof. Dr. Paul Bates (UK), İrşad Bayırhan (TR), Prof. Dr. Bülent Bayram (TR), Prof. Dr. Luis M. Botana (ES), Prof. Dr. Nuray Çağlar (TR), Prof. Dr. Sukanta Dash (IN), Dr. Soofia T. Elias (UK), Prof. Dr. A. Evren Erginal (TR), Assoc. Prof. Dr. Cüneyt Erenoğlu (TR), Dr. Dieter Fritsch (DE), Prof. Dr. Çiğdem Göksel (TR), Prof.Dr. Lena Halounova (CZ), Prof. Dr. Manik Kalubarme (IN), Dr. Hakan Kaya (TR), Assist. Prof. Dr. Serkan Kükrer (TR), Assoc. Prof. Dr. Maged Marghany (MY), Prof. Dr. Michael Meadows (ZA), Prof. Dr. Nebiye Musaoğlu (TR), Prof. Dr. Masafumi Nakagawa (JP), Prof. Dr. Hasan Özdemir (TR), Prof. Dr. Chryssy Potsiou (GR), Prof. Dr. Erol Sarı (TR), Prof. Dr. Maria Paradiso (IT), Prof. Dr. Petros Patias (GR), Prof. Dr. Elif Sertel (TR), Prof. Dr. Nüket Sivri (TR), Prof. Dr. Füsun Balık Şanlı (TR), Prof. Dr. Uğur Şanlı (TR), Duygu Ülker (TR), Prof. Dr. Seyfettin Taş (TR), Assoc. Prof. Dr. Ömer Suat Taşkın (TR), Assist. Prof. Dr. Tuba Ünsal (TR), Dr. Manousos Valyrakis (UK), Dr. İnese Varna (LV), Dr. Petra Visser (NL), Prof. Dr. Selma Ünlü (TR), Assoc. Prof. Dr. Oral Yağcı (TR), Prof. Dr. Murat Yakar (TR), Assoc. Prof. Dr. İ. Noyan Yılmaz (AU); Assit. Prof. Dr. Sibel Zeki (TR) 


\title{
Research Article
}

\section{Calculation of Aircraft Emissions during Landing and Take-Off (LTO) Cycles at Batumi International Airport, Georgia}

\author{
Aydin Tokuslu iD \\ Turkish Naval Forces, Ankara, Turkey \\ E-mail: aydintokuslu78@gmail.com \\ Received 10 Nov. 2020 \\ Accepted 12 Dec. 2019
}

How to cite: Tokuslu, A. (2021). Calculation of aircraft emissions during landing and take-off (LTO) cycles at Batumi International Airport, Georgia. International Journal of Environment and Geoinformatics (IJEGEO), 8(2): 186-192. doi. 10.30897/ijegeo.836780

\begin{abstract}
In this paper, aircraft emissions (nitrogen oxides, carbon monoxide, and hydrocarbons) were estimated during landing and take-off (LTO) cycles for the year 2018 at Batumi International Airport in Georgia. The calculation model is based on flight data recorded by TAV Airports Holding Corporations in Georgia, including type and number of aircraft, engine type, number of passengers, and emission factors from the International Civil Aviation Organization Engine Exhaust Emission Databank were used for estimating the emissions. The total aircraft emissions during the LTO cycle were assessed as $68.96 \mathrm{t} / \mathrm{y}$ (39.78 t/y for NOx, $25.92 \mathrm{t} / \mathrm{y}$ for CO, and $3.26 \mathrm{t} / \mathrm{y}$ for HC) at Batumi international airport. Domestic flights were accountable for $68 \%$ of the total LTO emissions in 2018 . The findings displayed that NOx was mainly released during the take-off and climb-out modes, accounting for $27 \%$ and $37 \%$ of the total emissions. $\mathrm{CO}$ and $\mathrm{HC}$ emissions were released mostly in taxi mode and responsible for $77 \%$ and $70 \%$ of total emissions. The assessment demonstrates that a 2-minute reduction in taxi mode results in an approximate $6 \%$ reduction in LTO emissions. To predict future emissions, it was evaluated that a 50\% increase in LTO cycles would result in an increase of approximately 55-60\% in emissions.
\end{abstract}

Keywords: Airport, Air Quality, Aircraft emissions, Emissions inventory, Air pollutants

\section{Introduction}

International aviation and maritime sectors have a significant contribution to the increase of air pollution and consequently the acceleration of climate change (Ülker et al., 2018). Aviation has an important place in the transportation sector and its impact on the atmospheric environment is increasing every year. Over half of the world's 1.1 billion tourists are transferred by air in 2015 , while aircraft carry $35 \%$ of world trade by value (ICAO, 2016a). International passenger movement increased its capacity by $6.7 \%$ in 2015 , up from the $6 \%$ recorded in 2014 and its capacity is expected to increase at an average annual rate of $2.5 \%$ by 2036 (FAA, 2016). This increase will also significantly affect aircraft emissions which are recognized as a serious, worldwide public health concern (Bayırhan et al., 2019; EPA, 2005; Penner et al., 2010; Mersin et al., 2020; Tokuslu, 2020; WHO, 2006).

The exhaust gas emissions generated from aircraft are mainly nitrogen oxides (NOx), hydrocarbons (HC), carbon monoxide $(\mathrm{CO})$, carbon dioxide $\left(\mathrm{CO}_{2}\right)$, sulphur oxides $(\mathrm{SOx})$, water vapor $\left(\mathrm{H}_{2} \mathrm{O}\right)$, particles and other gases (ICAO, 2011). Many studies have shown that air pollution from airports can negatively affect air quality, close to the airport, and even in the wider region (Rissman et al., 2013; Hudda and Fruin, 2016). Therefore, the effects of airport emissions on the environment continue to be important.
There is a large volume of published studies investigating aircraft emissions at airports and their detrimental effects on people. There is a consensus among scientists (Pope and Dockery, 2012; Krzyzanowski and Cohen, 2008; Barrett et al., 2010; Rissman et al., 2013; Hudda and Fruin, 2016) that emissions from airplanes negatively affect the health and life quality of people living in the region close to the airport, causing an increase in global air pollution. Stettler et al. (2011) examined the harmful effects of UK airport emissions on the environment and analysed the effects of airborne emissions on human health. Tokuslu (2020) estimated the aircraft emissions during LTO emissions at Tbilisi international airport. Vujović and Todorovic (2017) evaluated aircraft emissions at Nikola Tesla International Airport in Belgrade, Serbia, and pollutant trends at the airport using weather patterns. The airborne emissions from all civil airports in mainland China and measured the environmental impact of emissions using the air quality model were calculated by Bo et al. (2019). Yang et al. (2018) analysed the air pollutants and other emission sources at Beijing Capital International Airport using the aircraft meteorological data relay. $\mathrm{Yu}$ et al. (2020) examined the $\mathrm{CO}_{2}$ emissions from the Chinese civil aviation industry between 1979 and 2016, and the harmful effects of these emissions. Yilmaz (2017) predicted the aircraft emissions including nitrogen oxides, hydrocarbons, and carbon monoxide, during LTO cycles for the year 2010 at Kayseri Airport 
in Turkey. Zhou et al. (2019) developed a new concept to correct the analysis of aircraft emissions and established a relationship between aircraft flight time and height for different airports using aircraft meteorological data relay. Song and Shon (2012) analysed the emissions of greenhouse gases and air pollutants from airplanes at four major international airports in Korea for two years (2009-2010) using the dispersion modelling system.

The main purpose of this study is to estimate the aircraft emissions (NOx, CO, and HC) during LTO cycle at Alexander Kartveli Batumi International Airport of Georgia for the year 2018. No previous study has investigated the airborne emissions in Batumi international airport which makes this study noteworthy in this context. The calculation model is based on flight data recorded by TAV Airports Holding Corporations in Georgia, including type and number of aircraft, engine type and the number of passengers, etc. Emission factors from the ICAO Engine Exhaust Emission Databank (ICAO, 2016b) were used for estimating the emissions. Although Georgia is a member of the International Civil Aviation Organization and has adopted its requirements, it does not have a regulation or implementation to control aircraft emissions in the airspace. Therefore, this study will be an important guide for taking measures in this regard. The findings of the study should make a significant contribution to the field of emissions from aircraft.

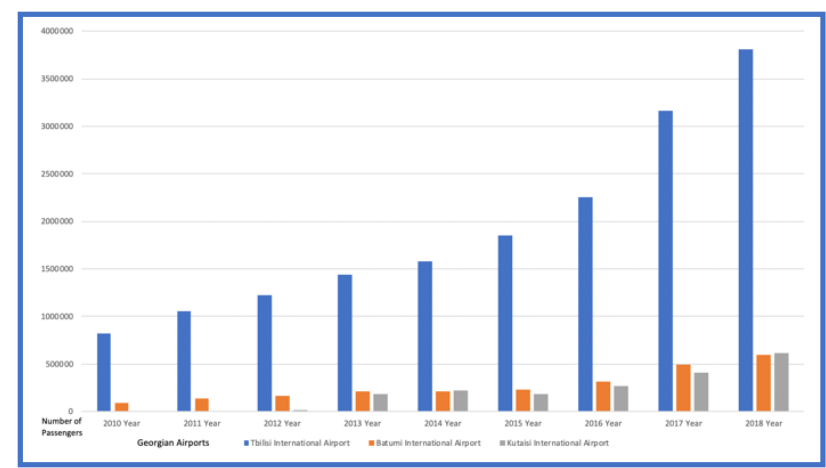

Fig. 1. Number of passengers at Georgian main airports (TAVAHC, 2019).

\section{Materials and Methods Study area}

Georgia is one of the Caucasian destinations preferred by tourists from all over the world as it is one of the former Soviet republics and located in the centre of the Caucasus culture. Transportation to the country is generally provided by air and land. Figure 1 displays the passenger tendencies for the period 2010-2018 at all Georgian commercial airports which are available for domestic and international flights (GCAA, 2019). As shown in Figure 1, there is an unceasing rise in the number of passengers at all airports and the quantity of passengers arriving in the country is rising by $9 \%$ every year. With the increase of the aircraft coming to the airports, the emissions generated by the aircraft also increase. Batumi is the second biggest city of Georgia and the capital of the Autonomous Republic of Adjara, situated on the coast of the Black Sea in Georgia's southwest. Batumi is a popular tourist attraction with tourism and gambling. Batumi international airport is one of three international airports in Georgia (along with Tbilisi International Airport, and David the Builder Kutaisi International Airport) with a total area of 4,256 square meters, and it is capable of handling 600,000 passengers a year. The airport is operated by TAV Airports Holding Corporations since 2007 (TAVAHC, 2019).

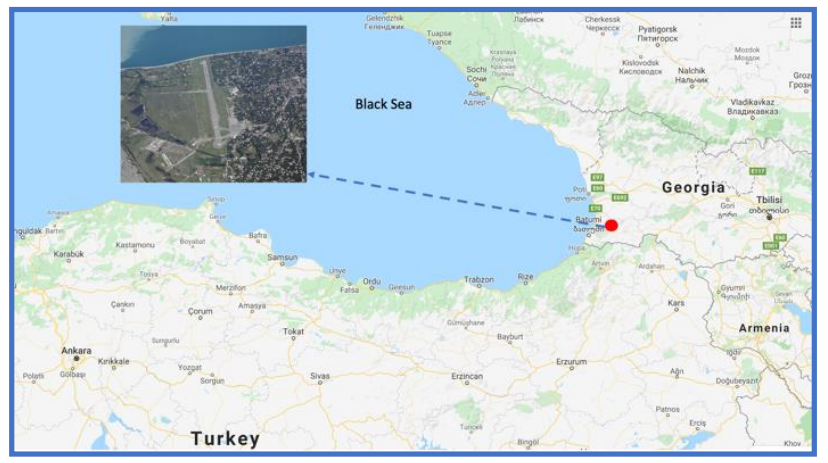

Fig. 2. Batumi International Airport (GMAPS, 2019).

\section{Airport traffic at Batumi International Airport}

Alexander Kartveli Batumi International Airport (BUS) is the second biggest airport in Georgia which is located on the southwest side of the country. BUS has only one domestic flight to Tbilisi and some international flights to different countries such as Turkey, Ukraine, and Russia. BUS is located approximately $2 \mathrm{~km}$ from the city centre, which is the main resort area of Georgia with approximately 121.806 populations. Figure 2 shows the location of Batumi International Airport (GMAPS, 2020).

BUS served approximately 598.891 passengers in 2018 (shown in Figure 1), BUS is the second largest airport in Georgia and it has 3.056 of the LTO cycle in 2018 (TAVAHC, 2019). Aircraft traffic at BUS has a parallel increase with being the centre of attraction and touristic destination. The use of the capacity of passengers was $84 \%$ in 2018 . The number of passengers using airports is increasing every year as well.

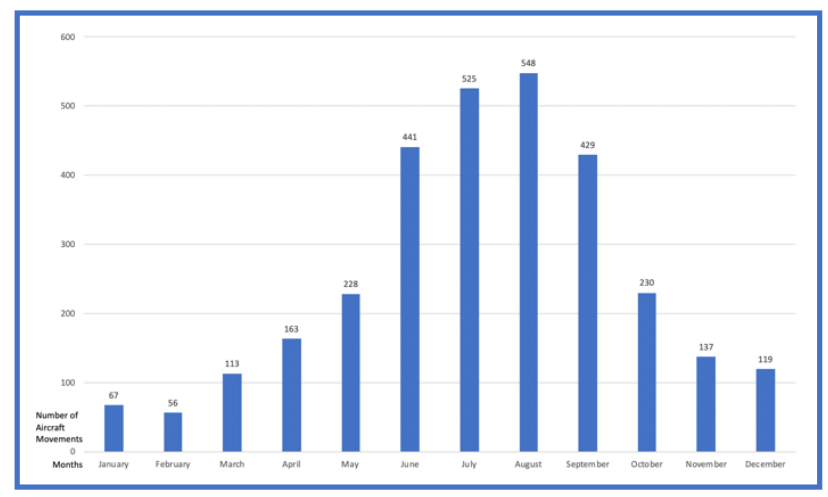

Fig. 3. The monthly distribution of aircraft movements (TAVAHC, 2019). 
The monthly distribution of aircraft movements is demonstrated in Figure 3 (TAVAHC, 2019). The peak months were August and July due to the resort season in the Black Sea, on these months 548 and 525 LTO cycles were recorded respectively. BUS also has a large mixture of aircraft types and the total aircraft types of
100 , including commercial and military aircraft. Figure 4 shows the distribution of aircraft types at BUS in 2018 (TAVAHC, 2019). As seen in Figure 4, B738s Boeing 737-800, A320 (Airbus 320), and A319 (Airbus 319) comprise half of all aircraft movements at BUS.

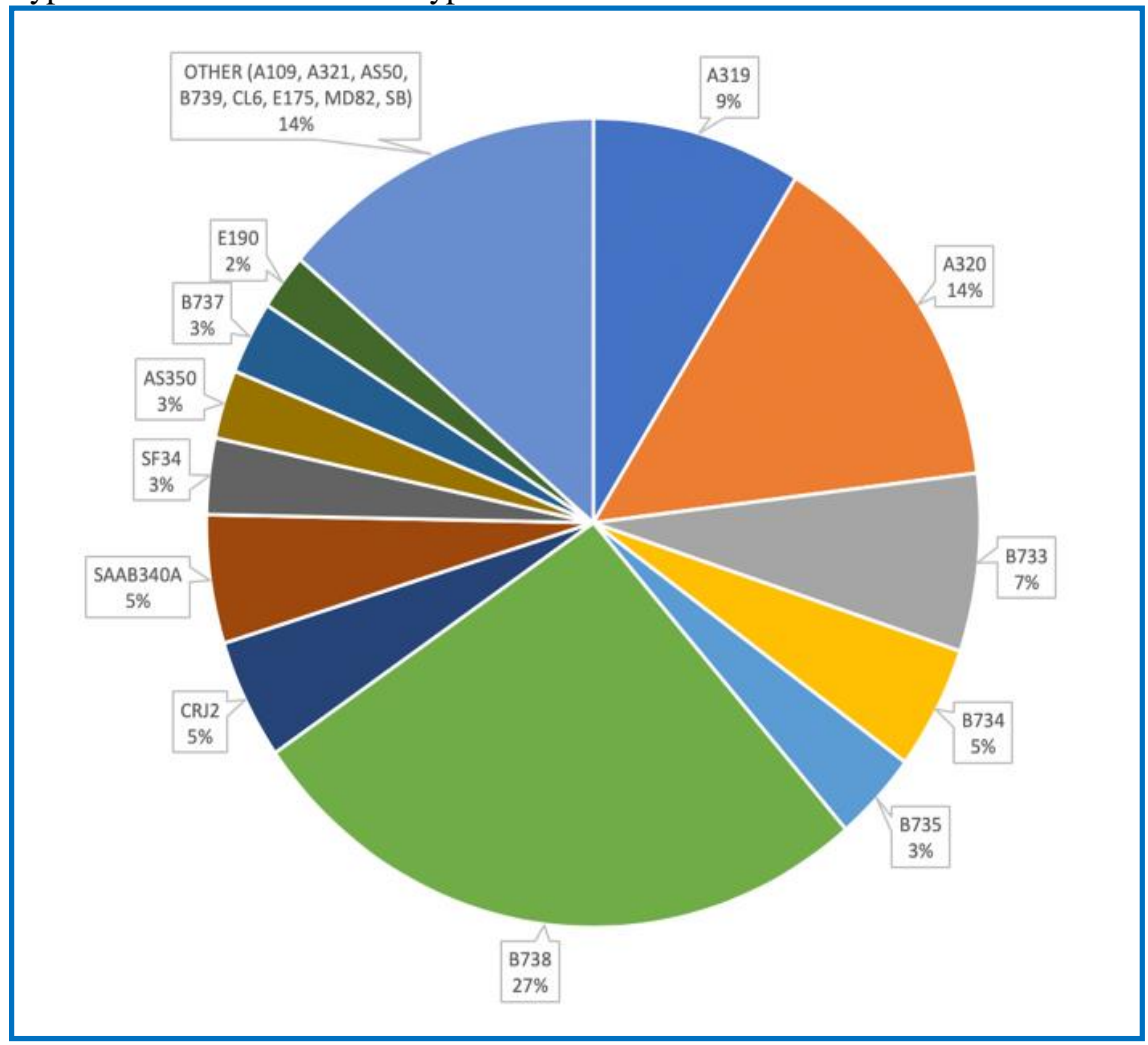

Fig. 4. The distribution of aircraft types (TAVAHC, 2019).

\section{Methodologies}

There are many methodologies used to estimate aircraft emissions. One of them was created by Kalidova and Kudrna (1997) which based on the type of aircraft and engine, LTO modes, and pollutants. This methodology is commonly used by assessing the emissions from aircraft in literature. The aircraft emissions at BUS are obtained by the following equation (Kalidova and Kudrna, 1997; Perl et al., 1997):

$$
\mathrm{E}_{i ; m}=\sum a \sum e n_{a} I_{a, e} F_{a, e, m} E_{e, m, i} t_{m, a}
$$

where,

$E_{i, m}$ : yearly emission of pollutant $\mathrm{i}$ for mode $\mathrm{m},\left(\mathrm{kg} / \mathrm{y}^{-1}\right)$, na: number of engines of aircraft type a,

$\mathrm{I}_{\mathrm{a}, \mathrm{e}}$ : number of annual LTO cycles for aircraft type a with engine type e,

$\mathrm{F}_{\mathrm{a}, \mathrm{e}, \mathrm{m}}$ : fuel consumption for aircraft type a with engine type e in mode $\mathrm{m},\left(\mathrm{kg} / \mathrm{y}^{-1}\right)$,

$\mathrm{E}_{\mathrm{e}, \mathrm{m}, \mathrm{i}}$ : emission factor for engine type e and mode $\mathrm{m}$ and pollutant $\mathrm{i},\left(\mathrm{g} / \mathrm{kg}^{-1}\right)$,

$\mathrm{t}_{\mathrm{m}, \mathrm{a}}$ : time in mode $\mathrm{m}$ for aircraft type a.
For this research, we examined the data gathered from TAV Airports Holding Corporations in Georgia which was included; type and number of aircraft and engine type. Aircraft emissions ( $\mathrm{HC}, \mathrm{CO}, \mathrm{NOx})$ at BUS airport are calculated for the LTO cycle which consists of four operation modes: approach, taxi, take-off, and climb-out (ICAO, 2011; Stettler et al., 2011; ICAO, 2016b). Standard LTO cycle times for approach, taxi, take-off, and climb-out were used for calculation as $4 \mathrm{~min}$ for approach, $26 \mathrm{~min}$ for taxi, $0.7 \mathrm{~min}$ for take-off, and 2.2 min for climb (ICAO, 2011; ICAO, 2016b) at BUS from the daily records of TAV Airports Holding Corporations (TAVAHC, 2019). Studies were carried out under the ideal ground and weather conditions. Emission factors from the ICAO Engine Exhaust Emission Databank (ICAO, 2016b) and Kalidova and Kudrna (1997) were used for estimating the emissions and fuel consumption (shown in Table 1). The fuel flow rates, type of engine, and emissions factors for $\mathrm{NOx}, \mathrm{CO}$, and $\mathrm{HC}$ were ensured by the databank. Stettler et al. (2011) and the engine manufacturer database were used for matching information between engine and type of aircraft. The LTO emissions assessed in this study only includes aircraft emissions, not covers other airport emissions. 
Table 1. Emission factors (ICAO, 2016b; Kalidova and Kudrna, 1997)

\begin{tabular}{|c|c|c|c|}
\hline Aircraft & CO (kg/LTO) & $\mathrm{NO}_{\mathrm{X}}(\mathrm{kg} / \mathrm{LTO})$ & HC (kg/LTO) \\
\hline Boeing 737 & 16.9 & 9.0 & 4.1 \\
\hline Boeing 727, 757 & 25.4 & 13.4 & 6.1 \\
\hline Boeing 747 & 65.8 & 47.7 & 19.6 \\
\hline Boeing 767, 707 & 119.1 & 11.6 & 99.0 \\
\hline Airbus A300, 310 & 119.1 & 11.6 & 99.0 \\
\hline Airbus A319 & 6.35 & 8.73 & 0.59 \\
\hline Airbus A320 & 24.6 & 9.7 & 5.9 \\
\hline Tupolev 154 & 25.4 & 13.4 & 6.1 \\
\hline Tupolev 134 & 24.6 & 9.7 & 5.9 \\
\hline Saab 340 & 22.1 & 0.3 & 14.1 \\
\hline DC9 & 16.9 & 9.0 & 4.1 \\
\hline $\mathrm{CRJ} 2$ & 4.14 & 4.41 & 0.04 \\
\hline Tupolev 154 & 25.4 & 13.4 & 6.1 \\
\hline Tupolev 134 & 24.6 & 9.7 & 5.9 \\
\hline Fokker F27 & 22.1 & 0.3 & 14.1 \\
\hline Fokker F28, 50, 100 & 64.1 & 8.2 & 47.1 \\
\hline Concorde & 384 & 41 & 112 \\
\hline
\end{tabular}

\section{Results}

213 aircraft were analysed during the LTO cycle, including climb-out, taxi, approach, and take-off at BUS. The whole fuel consumption for LTO cycles at BUS was assessed at around $3.392 \mathrm{t} / \mathrm{y}$ in the year 2018 using fuel flow rates for each aircraft type in the ICAO Databank. The percentages for take-off, climb-out, taxi, and approach are 12, 32, 37, and 19 at BUS, respectively.

Aircraft emissions for 2018 during the LTO cycle were estimated to be $68.96 \mathrm{t} / \mathrm{y}(39.78 \mathrm{t} / \mathrm{y}$ for NOx, $25.92 \mathrm{t} / \mathrm{y}$ for $\mathrm{CO}$, and $3.26 \mathrm{t} / \mathrm{y}$ for $\mathrm{HC}$ ) at Batumi international airport. The ratio of domestic flights of total flights was $68 \%$ and the ratio of domestic flight emissions to the total LTO emissions was $68 \%$ at BUS. It can be determined that international flights has around $32 \%$ of all emissions. The dispersal of aircraft emissions for LTO modes is seen in Figure 5 which shows that the taxi mode has the biggest portion of total LTO emissions at $40 \%$.

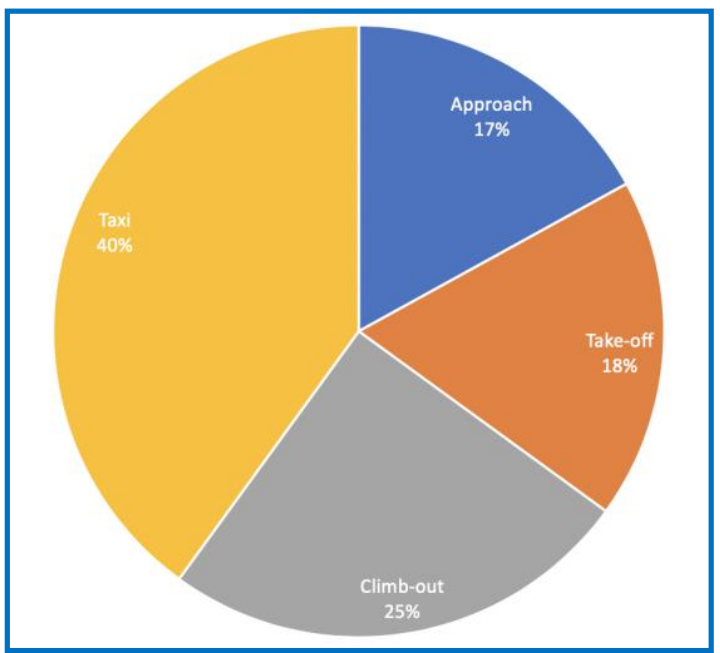

Fig. 5. The dispersal of aircraft emissions for LTO modes at BUS in 2018.

The climb-out mode composes the second biggest cause of LTO emissions at $25 \%$. The take-off and approach modes are accountable for $18 \%$ and $17 \%$, respectively.
The dispersal of aircraft emissions ( $\mathrm{HC}, \mathrm{CO}, \mathrm{NOx})$ for LTO modes is presented in Figure 6. The findings of the current study support the results (Stettler et al., 2011; Tokuslu, 2020; Yilmaz, 2017; Elbir, 2008) that emissions produced from the taxi mode are bigger than the other modes (take-off, climb-out, and approach) and taxi mode is the leading source of pollution in the airports. Taxi mode emissions can be decreased by declining the taxiing duration. If the airplane stays less in the mode of taxi and guided to taxi routes quicker with fewer stops and turns, emissions will be decreased considerably.

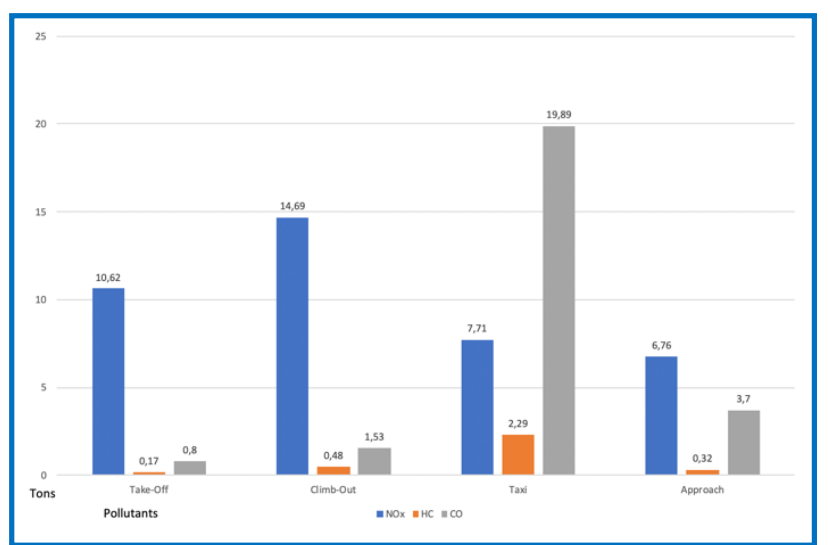

Fig. 6. The distributions of LTO emissions.

The duration of taxiing differs between 20 and 30 minutes. Figure 7 demonstrates that a 2 -minute reduction in taxi mode results in an approximate $6 \%$ reduction in LTO emissions and an approximately $9 \%$ reduction in LTO emission amount in taxi mode. From Figure 7, it can be determined that $\mathrm{NOx}, \mathrm{HC}$, and $\mathrm{CO}$ emissions increase with increasing taxiing time. Taxi mode emissions will account for $34 \%$ of the total LTO emissions as a result of reducing the taxi time from 26 to 20 minutes and a reduction of approximately $16 \%$ in the total amount of LTO emissions will also occur.

Figure 8 demonstrates the dispersals of take-off, climbout, taxi, and approach emissions including NOx, CO, and HC. The taxi mode has the largest emissions portions of LTO modes which is $77 \%$ for $\mathrm{CO}$ and $70 \%$ 
for $\mathrm{HC}$ and the climb-out mode has the second-largest emissions portions which are $37 \%$ for NOx. The take-off

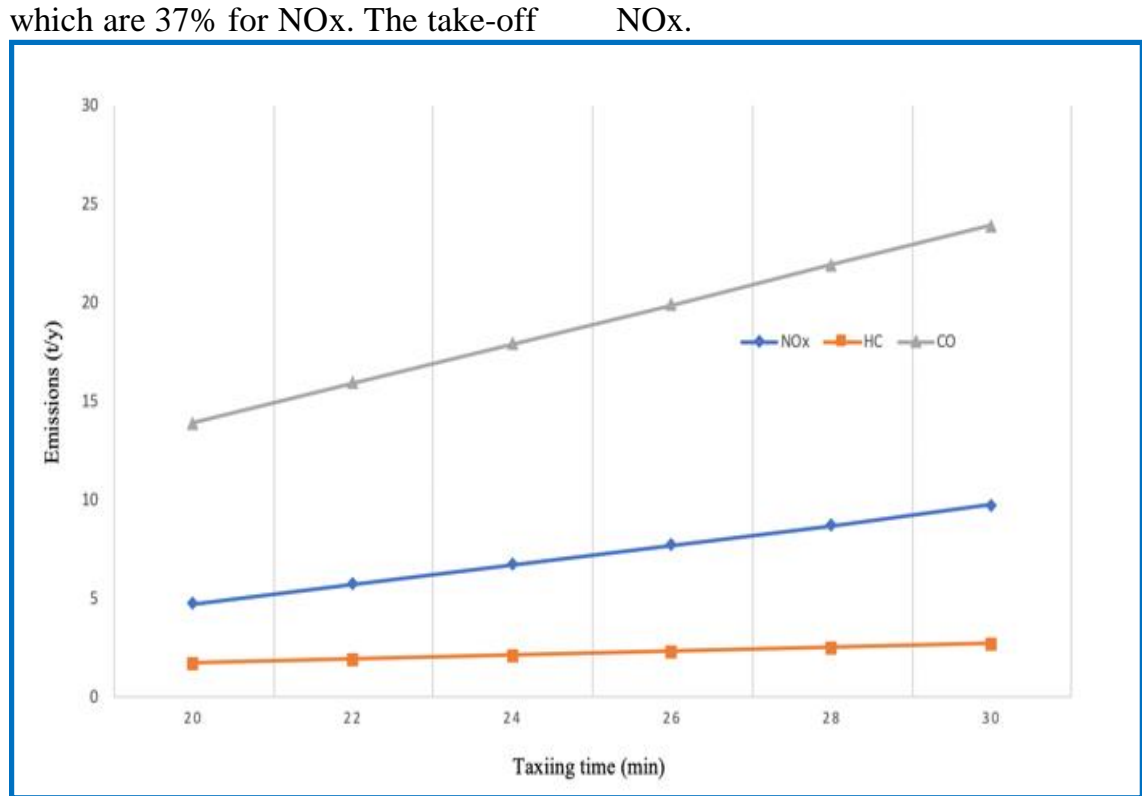

Fig. 7. Effect of taxiing time on LTO emissions.

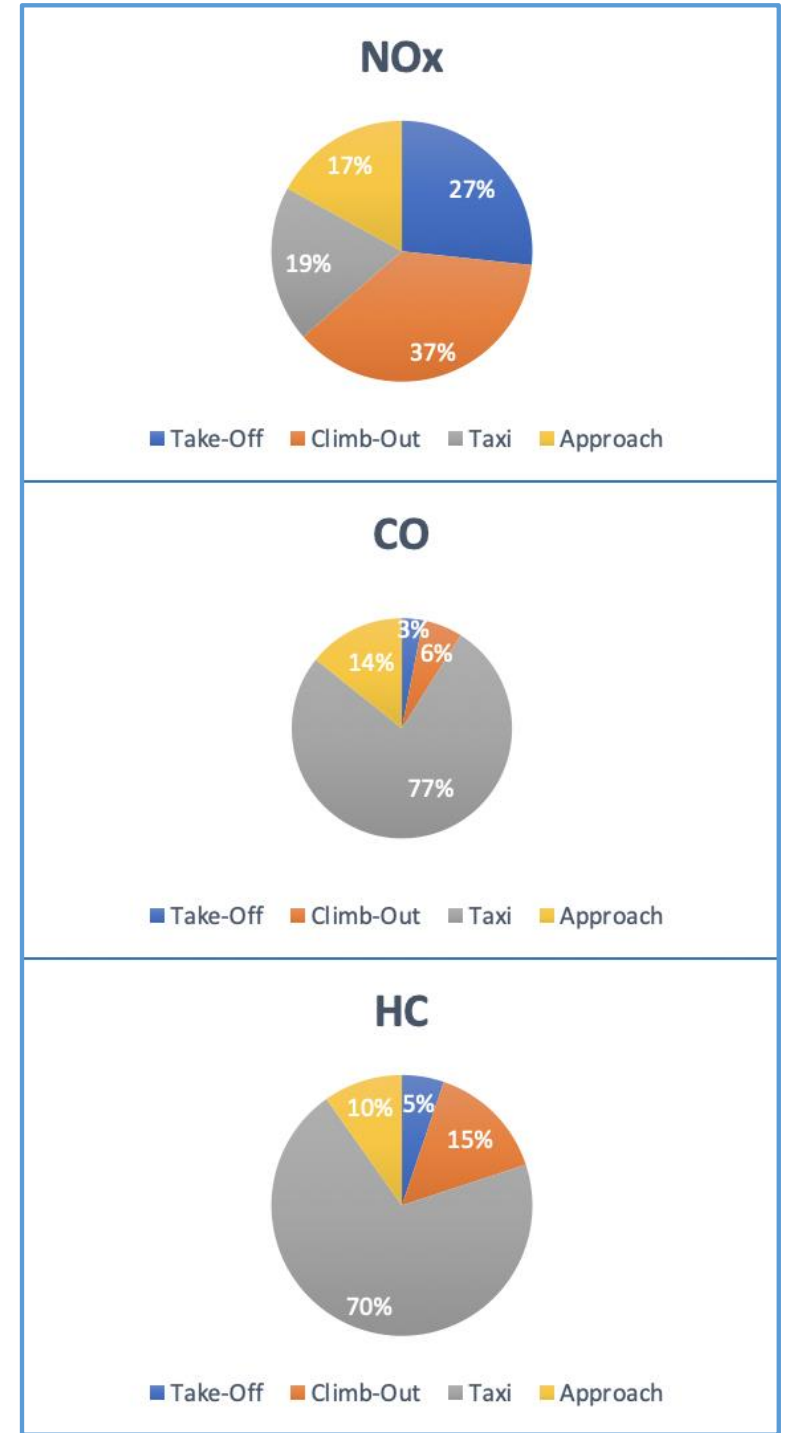

Fig. 8. The distribution of aircraft emissions (NOx, $\mathrm{CO}, \mathrm{HC}$ ) for LTO modes.

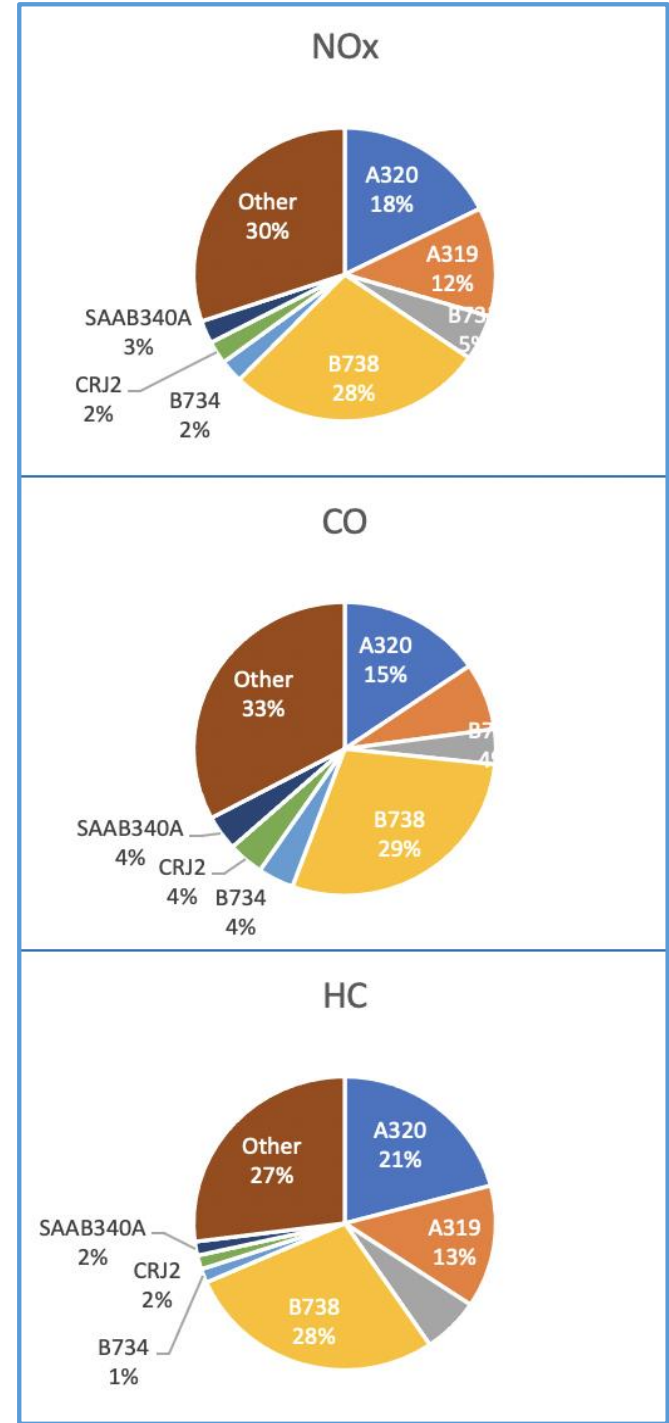

Fig. 9. The distribution of $\mathrm{NOx}, \mathrm{CO}$ and $\mathrm{HC}$ emissions from each type of aircraft. 
The distribution of NOx, CO, and $\mathrm{HC}$ emissions from each type of aircraft at BUS in 2018 is displayed in Figure 9. B738, A320, and A319 are accountable for half of all emissions. The NOx, $\mathrm{CO}$, and $\mathrm{HC}$ emission for B738 is $28,29,28 \%$ to the total emissions respectively, B738 has $27 \%$ of the aircraft movements at BUS. The A320 is the following pollutant aircraft which has 18 , 15, 21\% NOx, CO, and $\mathrm{HC}$ emissions respectively. There is a variance between the $\mathrm{NOx}, \mathrm{HC}$, and $\mathrm{CO}$ emissions ration of every aircraft, because of the emission factors for LTO modes (especially approach).
A319 is the third pollutant plane type which produces NOx, CO, and $\mathrm{HC}$ emissions at $12,7,13 \%$ respectively.

Comparisons of emissions at airports generated from aircraft are displayed in Table 2. When matched our findings to those of studies, it can be determined that our results seem to be consistent with other research (Elbir, 2008; Yilmaz, 2017; Tokuslu, 2020) which found that B738 and A320 are the main polluters in the studied airports. Emissions during LTO cycles in the BUS are less than emissions from a medium-sized airport due to the low capacity of the airport operating.

Table 2. Comparisons of aircraft emissions at airports (ton/year)

\begin{tabular}{|c|c|c|c|c|c|c|}
\hline Airport & Year & LTO Cycle & $\mathrm{NO}_{\mathrm{X}}$ & $\mathrm{CO}$ & HC & Reference \\
\hline Tbilisi & 2018 & 19.005 & 247.33 & 161.21 & 20.24 & Tokuslu (2020) \\
\hline Atlanta & 2000 & 423.423 & $4.91 E+03$ & $5.20 \mathrm{E}+03$ & $8.81 \mathrm{E}+02$ & Unal et al. (2005) \\
\hline Beijing & 2015 & 295.100 & $7.56 \mathrm{E}+03$ & $3.49 \mathrm{E}+03$ & $3.18 \mathrm{E}+02$ & Yang et al. (2018) \\
\hline Adnan Menderes & 2004 & 91.980 & 197 & 138 & 21 & Elbir (2008) \\
\hline Kayseri & 2010 & 7.887 & 102.64 & 66.9 & 8.4 & Yilmaz (2017) \\
\hline Incheon & 2010 & 214.835 & $3.65 \mathrm{E}+03$ & $1.75 \mathrm{E}+03$ & $2.73 \mathrm{E}+02$ & Song and Shon (2012) \\
\hline Boryspol & 2016 & - & 16.87 & 185.06 & 59.56 & $\begin{array}{l}\text { Zaporozhets and Synylo } \\
\text { (2017) }\end{array}$ \\
\hline Batumi & 2018 & 3.056 & 39.78 & 25.92 & 3.26 & This Study \\
\hline
\end{tabular}

\section{Assessing future emissions}

Batumi, which is a resort area for the Caucasus region and Central Asian countries, has an increasing visitor traffic every year. Tourist traffic increased by $17 \%$ on average from 2010 to 2018 (Figure 1). The number of tourists continued to increase after 2018, and air traffic increased in parallel with the increase in passengers and caused more air pollution. According to the projection made according to the information on passenger traffic and flight movements that took place between 2010 and 2018 , it was analyzed that the number of passengers and flights would increase by $50 \%$ until 2025 and the LTO cycle would be 4.500 (12 LTO cycles per day). The predicted increase in LTO cycles has also been seen in emission results, and a 50\% increase in LTO cycles has been calculated to result in an increase of approximately $55-60 \%$ in emissions. Projection results have shown that people living near the airport will continue to live under the harmful effects of emissions from airplanes in the future and people's sensitivity to air pollution will also increase.

\section{Discussion and Conclusion}

Aircraft emissions (HC, CO, NOx) during LTO cycles at Batumi international airport was calculated for the first time. The assessment of emissions during the LTO cycle was executed using flight data recorded by TAV Airports Holding Corporations in Georgia and emission factors of the ICAO Engine Exhaust Emission Databank were used for estimation. The effect of taxiing time on the LTO emissions was analysed in detail.

The total emissions generated from aircraft were calculated as $68.96 \mathrm{t} / \mathrm{y}(39.78 \mathrm{t} / \mathrm{y}$ for NOx, $25.92 \mathrm{t} / \mathrm{y}$ for $\mathrm{CO}$, and $3.26 \mathrm{t} / \mathrm{y}$ for $\mathrm{HC}$ ) at Batumi International Airport in 2018. Domestic flights were accountable for $68 \%$ of the total LTO emissions from all flights. Taxi mode emissions account for $40 \%$ of total LTO emissions. The climb-out mode constitutes $25 \%$ of LTO emissions, and the take-off and approach modes are accountable for $18 \%$ and $17 \%$, respectively. Since that taxi mode is the main cause of emission, it is assessed that the amount of emissions can be decreased by reducing the duration of taxiing. The assessment demonstrates that a 2-minute reduction in taxi mode results in an approximate $6 \%$ reduction in LTO emissions. It has been evaluated that a $50 \%$ increase in LTO cycles will result in an increase of approximately $55-60 \%$ in emissions and emissions generated from aircraft might continue to endanger the health and life quality of people living in the Batumi. The study is limited by the lack of information on health statistics which makes it hard to make assessment the effects of the aircraft emissions on human health. It is recommended that further research is recommended in the following areas: land and sea transport emissions in the region and their impact on human health. All these researches will help create emission inventory for the Caucasus region.

\section{Acknowledgments}

The author gratefully acknowledges the support of the TAV Airports Holding Corporations in Georgia for providing the flight data. This research did not receive any specific grant from funding agencies in the public, commercial, or not-for-profit sectors. The author wishes to express his sincere thanks to the editor of the International Journal of Environment and Geoinformatics (IJEGEO) for the support.

\section{References}

Barrett, S.R.H., Britter, R.E., Waitz, I.A. (2010). Global mortality attributable to aircraft cruise emissions. 
Environmental Science and Technology, 44 (19). 7736-7742, doi.org/10.1021/es101325r

Bayırhan, I., Mersin, K., Tokuslu, A., Gazioglu, C. (2019). Modelling of Ship Originated Exhaust Gas Emissions in the Istanbul Strait. International Journal of Environment and Geoinformatics (IJEGEO), 6(3): 238-243. doi.10.30897 /ijegeo.641397

Bo, X., Xue, X., Xu, J., Du, X., Zhou, B., Tang, L. (2019). Aviation's emissions and contribution to the air quality in China. Atmospheric Environment, 201 (2019) 121-131. doi.org/10.1016/j.atmosenv. 2019.01.005

Elbir, T. (2008). Estimation of engine emissions from commercial aircraft at a midsized Turkish airport. $J$. Environ. Eng., 134, 210-215. doi.org/10.1061/(ASCE)0733-9372(2008)134:3(210)

Environmental Protection Agency (EPA). (2005). Regulatory Announcement No. EPA420-F-05-015, Office of Transportation and Air Quality.

Federal Aviation Administration (FAA). (2016). Aerospace Forecast, Fiscal Year 2016-2036

Georgian Civil Aviation Agency (GCAA). (2019). Flight schedule, statistics. http://gcaa.ge/eng/regular.php

Google maps (GMAPS). (2019).

Hudda, N., Fruin, S.A. (2016). International airport impacts to air quality: size and related properties of large increases in ultrafine particle number concentrations. Environ. Sci. Technol., 50 (7), 33623370. doi.org/10.1021/acs.est.5b05313

International Civil Aviation Organization (ICAO). (2011). Airport Air Quality Manual.

International Civil Aviation Organization (ICAO). (2016a). Air Navigation Report.

International Civil Aviation Organization (ICAO). (2016b). Aircraft Engine Emissions Databank.

Kalivoda, M.T., Kudrna, M. (1997). Methodologies for estimating emissions from air traffic: future emissions. Cost 319 Action, report no. MEET Project ST-96-SC.204, Vienna, Austria; 1997, Perchtoldsdorf-Vienna.

Krzyzanowski, M., Cohen, A. (2008). Update of WHO air quality guidelines. Air Quality, Atmosphere, and Health (1), 7-13. doi. 10.1007/s11869-008-0008-9

Mersin, K., Bayırhan, İ., Gazioğlu, C. (2020). Analysis of the Effects of $\mathrm{CO} 2$ Emissions Sourced by Commercial Marine Fleet by using Energy Efficiency Design Index, Thermal Science, 24(1).187-197.

Mersin, K., Bayırhan, İ., Gazioğlu, C. (2019). Review of C02 Emission and Reducing Methods in Maritime Transportation, Thermal Science, 23(6).73-79. doi.org/10.2298/TSCI190722372M.

Penner, J.E., Lister, D.H., Griggs, D.J., Dokken, D.J., McFarland, M. (2010). Aviation and the Global Atmosphere. A Special Report of the Intergovernmental Panel on Climate Change. Cambridge University Press, Cambridge.

Perl, A., Patterson, J., Perez, M. (1997). Pricing aircraft emissions at Lyon-Satolas airport. Transport Res Part D., 1997;2(2):89-105. doi.org/10.1016/S13619209(97)00005-9.
Pope, C.A., Dockery, D.W. (2012). Health effects of fine particulate air pollution: lines that connect. Journal of the Air\&Waste Management Association,56,709742.doi.org/10.1080/10473289.2006.10464485

Rissman, J., Arunachalam, S., Woody, M., West, J.J., BenDor, T., Binkowski, F.S. (2013). A plume-in-grid approach to characterize air quality impacts of aircraft emissions at the Hartsfield-Jackson Atlanta International Airport. Atmos. Chem. Phys. Discuss., 13 (18), 9285-9302. doi.org/10.5194/acp-13-92852013

Song, S.K., Shon, Z.H. (2012). Emissions of greenhouse gases and air pollutants from commercial aircraft at international airports in Korea. Atmos.Environ., 61(61),148-158. doi:10.1016/j.atmosenv.2012.07.035

Stettler, M.E.J., Eastham, S., Barrett, S.R.H. (2011). Air quality and public health impacts of UK airports, Part I: Emissions. Atmospheric Environment, 45 (2011), 5415-5424. doi:10.1016/j.atmosenv.2011.07.012

TAV Airports Holding Corporations (TAVAHC). (2019).

Tokuslu, A. (2020). Estimation of aircraft emissions at Georgian international airport. Energy, 206 (2020), 118219. doi.org/10.1016/j.energy.2020.118219

Ülker, D., Ergüven, O., Gazioğlu, C. (2018). Socioeconomic impacts in a Changing Climate: Case Study Syria. International Journal of Environment and Geoinformatics, 5(1), 84-93.doi. 10.30897/ijegeo.406273.

Unal, A., Hu, Y., Chang, M., Odman, M., Russell, A. (2005). Airport related emissions and impacts on air quality: application to the Atlanta international airport. Atmos. Environ., 39(32):5787-5798. doi: 10.1016/j.atmosenv.2005.05.051

Vujović, D., Todorovic, N. (2017). An assessment of pollutant emissions due to air traffic at Nikola Tesla International Airport, Belgrade, and the link between local air quality and weather types. Transportation Research Part D., 56 (2017), 85-94. doi.org/10.1016/j.trd.2017.08.003.

World Health Organization (WHO). (2006). WHO Air Quality Guidelines for Particulate Matter, Ozone, Nitrogen Dioxide and Sulfur Dioxide. Global Update 2005. Summary of Risk Assessment.

Yang, X., Cheng, S., Lang, J., Xu, R., Lv, Z. (2018). Characterization of aircraft emissions and air quality impacts of an international airport. Journal of Environmental Sciences, 72(2018)198-207. doi.org/10.1016/j.jes.2018.01.007

Yilmaz, I. (2017). Emissions from passenger aircraft at Kayseri airport, Turkey. Journal of Air Transport Management, 58 (2017), 176-182. doi.org /10.1016/j.jairtraman.2016.11.001

Yu, J., Shao, C., Xue, C., Hu, H. (2020). China's aircraftrelated $\mathrm{CO} 2$ emissions: Decomposition analysis, decoupling status, and future trends. Energy Policy, 138 (2020), 111215. doi.org/10.1016/ j.enpol.2019.111215

Zaporozhets, O., Synylo, K. (2017). Improvements on aircraft engine emission and emission inventory asesessment inside the airport area. Energy, 140 (2017), 1350-1357. doi.org/10.1016/j.energy. 2017.07.178

Zhou, Y., Jiao, Y., Lang, J., Chen, D., Huang, C., Wei, P., Li, S., Cheng, S. (2019). Improved estimation of air pollutant emissions from landing and takeoff cycles of civil aircraft in China. Environmental Pollution, 249 (2019), 463-471. doi.org/10.1016/ j.envpol.2019.03.088. 